\title{
Risk and prevention of meningococcal disease among education workers: A review
}

\author{
Philippe De Wals MD PhD ${ }^{1,2,3}$, Pierre Deshaies MD MSc${ }^{4}$, Gaston De Serres MD PhD ${ }^{1,2,3}$, \\ Bernard Duval MD MSc ${ }^{1,3}$, Lise Goulet MD PhD ${ }^{1,5}$, Bernard Pouliot MD MPH ${ }^{6}$, \\ Sylvie Ricard $\mathrm{MSc}^{1}$, Maurice Poulin MD MSc ${ }^{1}$
}

\begin{abstract}
P De Wals, P Deshaies, G De Serres, et al. Risk and prevention of meningococcal disease among education workers: A review. Can J Infect Dis 2004;15(2):89-93.
\end{abstract}

The aims of the present study were to review the risk of invasive meningococcal disease (IMD) among education workers, particularly pregnant women, and to evaluate preventive measures, in a context of endemicity, outbreak or epidemic as observed in the province of Quebec. The literature was reviewed and persons in charge of IMD surveillance in France, Quebec, the United Kingdom and the United States were interviewed. Surveys of asymptomatic carriage of Neisseria meningitidis show that transmission among students is higher than transmission between students and teachers. IMD incidence among education workers was analyzed in Cheshire (United Kingdom) in the period from 1997 to 1999, and the results indicated a risk six times higher than that in the general population. Overestimation of the magnitude of the risk is possible because the analysis focused on a cluster. None of the population-based studies of IMD mentioned a risk of secondary cases among education workers. Six IMD cases in education workers were identified in five clusters in schools in the United Kingdom, but not in the other countries. There is no epidemiological study on IMD risk among pregnant women, and this factor was not mentioned in any published review of IMD. Immunization of education workers at the beginning of their employment, using serogroup $\mathrm{C}$ glycoconjugate vaccine or a combined $\mathrm{A}, \mathrm{C}$, $\mathrm{W}-135$, and $\mathrm{Y}$ conjugate vaccine (still under development), could reduce IMD risk, but the cost effectiveness of this measure should be evaluated. The societal benefit of excluding pregnant women from the work place during an outbreak seems to be very low, even if disease risk could be decreased for this specific group. When chemoprophylaxis is indicated for the control of an outbreak in an educational setting, treatment should be offered both to students and teachers in the group at risk.

Key Words: Disease risk; Education; Neisseria meningitidis; Occupational health; Prevention

\section{Survol du risque de maladie à méningocoque et de sa prévention en milieu scolaire}

La présente étude s'était donné comme objectif d'évaluer dans un premier temps le risque de transmission de la maladie à méningocoque invasive (MNI) au personnel enseignant, particulièrement aux femmes enceintes, et dans un deuxième temps, les mesures préventives dans un contexte d'endémicité, d'éclosion ou d'épidémie observé au Québec. Après revue de la littérature pertinente, des responsables français, québécois, britanniques et états-uniens de la lutte contre la MNI ont été interrogés. Selon des enquêtes sur le statut des porteur asymptomatique de Neisseria meningitidis, la transmission serait plus fréquente entre étudiants qu'entre étudiants et enseignants. Une analyse de l'incidence de la MNI chez le personnel enseignant a été effectuée dans le Cheshire (Royaume-Uni) pour la période allant de 1997 à 1999 et selon les résultats, le risque serait six fois plus grand que dans la population en général. Il est possible que la surestimation du risque soit une résultante de la nature typologique de l'analyse. Aucune des études de population sur la MNI n'a mentionné un risque de transmission secondaire au personnel enseignant. Six cas de MNI affectant des enseignants ont été identifiés dans cinq agrégats dans des écoles du Royaume-Uni uniquement. Aucune étude épidémiologique ne s'est penchée sur le risque de MNI chez les femmes enceintes et ce facteur n'a pas été mentionné dans la littérature publiée sur le sujet. L'immunisation des enseignants en début de mandat au moyen d'un vaccin glycoconjugué du sérogroupe $\mathrm{C}$ ou d'un vaccin conjugué combiné A, C, W-135 et Y (en cours d'élaboration) pourrait réduire le risque de $\mathrm{MNI}$, quoique le rapport coût-efficacité de cette mesure reste à évaluer. Il semble très peu avantageux de retirer les femmes enceintes de leur milieu de travail durant une éclosion, même si le risque de maladie peut en être diminué chez ce groupe en particulier. Lorsque la chimioprophylaxie est indiquée pour maîtriser une éclosion en milieu scolaire, le traitement doit être offert tant aux élèves qu'aux professeurs du groupe à risque.

$\mathrm{n}$ epidemic of invasive meningococcal disease (IMD)
Quebec in the early 1990s, and resulted in a mass immuniza-
tion campaign with the polysaccharide vaccine during the

winter of 1992 to 1993 (1). A recrudescence was detected at the beginning of 2001 and it was decided to offer the new serogroup C conjugate meningococcal vaccine to all Quebec persons up to 20 years of age (2). In this epidemiological

${ }^{1}$ Institut national de Santé publique du Québec, Quebec City, Quebec; ${ }^{2}$ Département de Médecine sociale et préventive, Université Laval, Quebec City, Quebec; ${ }^{3}$ Centre de Recherche du Centre hospitalier universitaire de Québec, Quebec City, Quebec; ${ }^{4}$ Département clinique de santé publique de l'Hôtel-Dieu de Lévis et Direction de santé publique de Chaudière-Appalache, Lévis, Quebec; ${ }^{5}$ Département de Médecine sociale et préventive, Université de Montréal, Montreal, Quebec; ${ }^{6}$ Régie régionale de la santé et des services sociaux du Bas-St-Laurent, Rivière-du-Loup, Quebec

Correspondence and reprints: Dr Philippe De Wals, Département de Médecine sociale et préventive, Université Laval, Pavillon de l'Est, 2180 chemin Sainte-Foy, Suite 1108, Quebec City, Quebec G1K 7P4. Telephone 418-656-2131 ext 7374, fax 418-656-7759, e-mail Philippe.Dewals@msp.ulaval.ca

Received for publication August 6, 2003. Accepted January 22, 2004 
TABLE 1

Annual incidence rate per million of invasive meningococcal disease according to serogroup and age, in the endemic period from 1995 to 1998, in Canada

\begin{tabular}{|c|c|c|c|c|c|c|c|c|}
\hline \multirow[t]{2}{*}{ Serogroup } & \multicolumn{7}{|c|}{ Age-group in years } & \multirow[b]{2}{*}{ All } \\
\hline & $0-9$ & $10-19$ & $20-29$ & $30-39$ & $40-49$ & $50-59$ & $60+$ & \\
\hline$A$ & - & - & - & 0.1 & 0.1 & - & - & 0.1 \\
\hline$B$ & 14.4 & 3.2 & 1.9 & 0.7 & 0.8 & 1.4 & 1.2 & 3.0 \\
\hline C & 6.2 & 5.2 & 2.5 & 0.7 & 0.9 & 0.8 & 1.0 & 2.3 \\
\hline W-135 & 0.6 & 0.2 & 0.1 & - & 0.1 & 0.2 & 0.1 & 0.1 \\
\hline $\mathrm{Y}$ & 1.1 & 1.0 & 0.3 & 0.3 & 0.4 & 0.2 & 1.3 & 0.7 \\
\hline Others & - & 0.1 & 0.1 & - & 0.1 & - & 0.1 & 0.1 \\
\hline Unknown* & 5.0 & 3.3 & 1.7 & 0.8 & 0.9 & 0.8 & 1.2 & 1.8 \\
\hline All & 27.3 & 12.9 & 6.6 & 2.6 & 3.2 & 3.4 & 4.8 & 8.1 \\
\hline
\end{tabular}

*Includes missing and nongroupable. Data from Health Canada (written communication)

situation, characterized by numerous cases of IMD in day care centres and educational institutions, the question arose whether staff should be immunized and pregnant women removed from the work place. Quebec's occupational health and safety legislation provides for the elimination of dangers to workers' health and for protection of workers when necessary (3). In addition, there is a provision that allows for the protective reassignment of pregnant women when working conditions may be physically dangerous to them or their unborn child. The aims of the present study were to estimate the risk of IMD for workers in the education system, pregnant women in particular, and to evaluate the potential effectiveness and usefulness of various preventive measures including temporary exclusion from the work place, immunization and chemoprophylaxis.

To address these questions, we did a critical review of the scientific literature using Medline and a series of key words (Neisseria meningitidis, meningococcal, school, college, nursery, university, cluster, outbreak). The personal archives of the authors covering the epidemiology of IMD during the past thirty years were also consulted. Finally, the persons in charge of IMD surveillance in the United States, France, Quebec and the United Kingdom were questioned to identify clusters involving staff in the education system.

\section{Risk of nasopharyngeal infection}

The natural habitat of $N$ meningitidis is the human nasopharynx and the bacterium is transmitted by direct mouth-to-mouth contact or by the excretion and inhalation of mucous particles during close contact (4). In a given community, the IMD risk depends on the acquisition rate of a pathogenic strain by susceptible individuals. For an individual, this risk is determined by the prevalence of carriers of pathogenic strains among the person's contacts, and the frequency and closeness of interpersonal contacts.

To date, there has been no study specifically concerned with the asymptomatic carriage of $N$ meningitidis among education workers. Generally, the prevalence of carriage is low among young children and higher among adolescents and young adults (5). The educational environment is conducive to the transmission of the bacterium. In England, a prospective study of first-year university students showed an increase in the proportion of carriers during the first term from $7 \%$ at admission to $23 \%$ a month later (6). Risk factors for acquisition were frequency of visits to bar halls, active smoking, visits to night clubs and intimate kissing.

In a situation of recrudescence caused by a virulent strain of serogroup $\mathrm{C}$, the prevalence of asymptomatic carriage of the pathogenic strain is usually very low in the general population, with values below 1\% (7-9). Higher prevalences may be observed among those in direct contact with a sick person. In England, the pathogenic strain was found in seven of the 34 classmates of a sick student $(21 \%)$, but only in one of the 209 students in other classes $(0.5 \%)$ and in none of the eight teachers at the elementary school (10). In another study, a high prevalence ( 50 of 572 , or $9 \%$ ) was found in students at a college in Devon, United Kingdom, following an outbreak caused by a serogroup C strain, while 3\% (4 of 154) of the staff members were carriers (11).

Similar observations have been made in the context of an outbreak caused by serogroup B strains. Studies of asymptomatic nasopharyngeal carriage done in several high schools in Wales showed prevalences of the pathogenic strain of about $2 \%$ among the students $(12,13)$. In a study of the contacts of sick people in Norway, the prevalence of the pathogenic strain was $1 \%$ among fellow day-care users (two of 220), $1 \%$ among classmates (four of 286), $0 \%$ among the teachers (zero of 44), and very low $(0.7 \%)$ in the general population (14).

\section{Risk of invasive infection}

In Canada, as in other industrialized countries, most IMD occur in people under age 20 and the risk is low among adults (15). Epidemiological surveillance data in Table 1 indicate that annual IMD incidence was about 4 per million in the adult population, during the endemic period of 1995 to 1998 (Health Canada, written communication). In the population aged 20 to 59 years, $43 \%$ of cases of known serogroup were of serogroup C, $11 \%$ of serogroup Y, 3\% of serogroup W-135, and $2 \%$ of serogroup A. In the period 1990 to 1992 , and in the period 1999 to 2001, outbreaks caused by virulent strains of serogroup C N meningitidis were observed in several Canadian provinces. During these outbreaks, an increased proportion of cases occurred in young adults (16). In the 25- to 44-year-old age group, in Quebec, the risk of serogroup C IMD was 3.0 per million person-years during the epidemic period (1990 to 1995), and was 0.4 per million during the endemic period 
(1996 to 2000) (Quebec Ministry of Health, written communication). In recent years, a slight increase in serogroup $\mathrm{Y}$ incidence was observed in Ontario, but not in the other provinces and territories (17). Since 2000, small outbreaks caused by serogroup W-135 strains, associated with Hajj pilgrims returning from Saudi Arabia, have been reported in the United Kingdom, France and the United States, but not in Canada (18).

In adults, risk factors for IMD include underlying immune deficiency, low socioeconomic status, household and institutional crowding, tobacco smoke exposure, and bar and nightclub patronage (19). Both clinical presentation and the severity of disease varies according to age and the serogroup. In a study of IMD adult cases notified in Quebec, from 1990 to 1994, the highest rate of complication was in 20- to 59-yearold adults with serogroup $\mathrm{C}$ infection, and the fatality rate was $20 \%$. In the same age group, case fatality rate was only $5 \%$ in serogroup B infections (20). Permanent physical sequelae were present in $25 \%$ of survivors with serogroup $\mathrm{C}$ infection, and in $12 \%$ of those with serogroup B infection (20).

A study was done in the United Kingdom to quantify the risk of IMD among education workers (21). After notification of several cases of IMD among teachers in Cheshire, a review of the 50 adult cases notified in 1997 to 1999 identified seven cases among education workers and calculated an attack rate of $41.2 / 100,000$ in this group compared with a rate of 7.8/100,000 for the entire population, between age 20 and 65 years, in the region (relative risk of $6.0,95 \%$ CI 2.8 to 13.1 ; attributable risk fraction among teachers of $83 \%$, 95\% CI $64 \%$ to $92 \%$ ). However, this result should be interpreted with caution because the study was done in a context of a high incidence of IMD and the analysis focused on the area including the initial cluster and covered a short period of time (three years). This type of approach may result in the risk being overestimated (22). Analyzing the professional risk for the entire United Kingdom and over a longer period of time may have resulted in a lower excess risk. To estimate the risk of IMD among health care and laboratory workers, the reference population was the entire population of England and Wales and the study period was 15 years $(23,24)$. Ideally, the initial cluster which raised the hypothesis of an excess risk among education workers should be excluded from the study aiming to test this specific hypothesis.

\section{Risk of secondary cases}

There are numerous reports in the literature of clusters of IMD in day care centres (25-28), elementary and high schools (29-32), colleges (11) and universities (33), and a few systematic epidemiological studies (34-38). None of these publications mentions the existence of a risk of infection among the teaching staff. However, five clusters reported in England and Wales between 1995 and 1998 involved a staff member of an educational institution; of the six people infected, three were teachers and three were interns or assistants (James M Stuart, written communication). The staff member was the index case in four of these five clusters and the secondary case in the fifth. Furthermore, there have been no reports of clusters involving staff members in educational institutions in recent years in the United States, France and Quebec (Nancy Rosenstein, written communication; Anne Perrocheau, written communication; Monique DouvilleFradet, written communication).

\section{Risk for pregnant women}

There are no epidemiological studies on the risk of IMD among pregnant women, but this factor is not mentioned in any of the literature reviews $(5,39,40)$. In Quebec, we know of two IMD cases during pregnancy since 1990, and neither involved educators (Monique Douville-Fradet, written communication). Although there is no indication of an increased risk of IMD associated with pregnancy, it is logical to assume that the seriousness of the disease could affect the health of the fetus. In the first case observed in Quebec, a meningococcemia caused by a serogroup $C$ strain occurred in the 38th week of pregnancy and brought on premature labour and the birth of a child who developed a cerebral palsy syndrome. In the second case, a febrile syndrome appeared in a woman who was 38 weeks pregnant. A blood hemoculture showed an infection by a serogroup B meningococcus. Antibiotic therapy resulted in a favourable outcome and a child in apparently good health was born after a 39 week pregnancy.

\section{Immunization}

Immunization is the best way to prevent IMD. Polysaccharide vaccines against serogroups $A, C, Y$ and $W-135$ have existed for decades, but the protection is short-lived (41) and these vaccines are not recommended for routine immunization aiming to confer long-term protection (16). Serogroup C glycoconjugate vaccines are now available in Canada and their short-term effectiveness is approximately $90 \%$ in all age groups $(42,43)$. This type of vaccine triggers the appearance of an immunological memory and it is likely that the protection will last a long time (44). Combined A, C, W-135 and Y glycoconjugate vaccines are presently under development, and may be available in a near future (44).

Assuming that education workers begin their professional careers at age 25 and at that time they receive a dose of serogroup $\mathrm{C}$ meningococcal conjugate vaccine, which will provide $90 \%$ protection against the disease for 20 years, it would be necessary to vaccinate between 8000 and 46,000 workers to prevent one IMD case (assuming the relative risk of the disease is 6 or 1 compared with the general population and annual incidence rates in the general population as reported in Table 1). Using a combined A, C, W-135 and Y conjugate vaccine and the same assumptions on disease incidence and vaccine efficacy, it would be necessary to vaccinate between 6000 and 34,000 workers to prevent one IMD case.

\section{Protective work reassignment}

There are no studies regarding the effectiveness of exclusion from work during a recrudescence or cluster, and this preventive measure is not mentioned in the guidelines for the control of IMD in the United States and Canada $(45,46)$. The temporary reassignment of a pregnant teacher away from students in an epidemic situation or during a local outbreak could possibly reduce the risk of infection for this specific group, but the societal benefit would be virtually nil because the workers would have to be replaced and other individuals would be exposed.

\section{Chemoprophylaxis}

The effectiveness of chemoprophylaxis in preventing IMD in the close contacts of a sick person has been studied in noncontrolled epidemiological studies in families (47-49). The protection conferred by chemoprophylaxis is short-lived and the reduction in the risk may be effective in a given community, 
provided all the individuals are treated simultaneously. American and Canadian guidelines advocate chemoprophylaxis following a sporadic case in a day care centre $(45,46)$, but not in institutions with older children. However, extended chemoprophylaxis is sometimes the only way to try to control an outbreak in an educational institution when the strain is not covered by a vaccine or when quick protection is the aim (50-52).

In February 2001, at the beginning of the serogroup C outbreak in the province of Quebec, four IMD cases occurred during a nine-day period, in 13- to 16-year-old adolescents attending the same large secondary school in the Monteregie area (Montérégie Regional Health Board, written communication). In two of these cases, the diagnosis was made on clinical grounds. The two other cases were confirmed by culture and the epidemic serogroup C 2a P1.2,5 ET15 clone was identified. Interestingly, the four affected adolescents had been immunized with one dose of polysaccharide vaccine during the 1992-1993 mass immunization campaign. To prevent any new cases possibly caused by transmission at the school, chemoprophylaxis and vaccination was immediately offered to all the students (approximately 2278) and adults (approximately 756) in the school. A total of 2700 individuals received one dose of polysaccharide vaccine ( $89 \%$ of target population), and a twoday rifampin regimen was prescribed to 2718 individuals (90\% of target population). Among 541 students who responded to a survey, $89 \%$ fully complied with the prescribed chemoprophylaxis, $7 \%$ partially complied and $4 \%$ did not take the drug. No other IMD cases were observed in the school.

In such a situation, the objective is to interrupt the transmission of the pathogenic strain, before the immune response to the vaccine becomes effective. The treatment of all the individuals belonging to the target community is indicated, including teaching staff. Recommended drugs, regimens, indications and contraindications for chemoprophylaxis are provided in the Canadian guidelines for control of meningococcal disease (46).

\section{CONCLUSION}

The educational environment is conducive to the transmission of meningococcus and staff may be exposed to an increased risk of infection from their work. The extent of the absolute risk of IMD attributable to professional exposure is difficult to quantify but appears to be low, even in a situation of a generalized recrudescence or outbreak in an institution. Given the high cost of the serogroup $\mathrm{C}$ meningoccal conjugate vaccine (approximately $\$ 30$ to $\$ 50$ per dose for the public sector in Canada), systematic immunization of this professional group should be economically evaluated in comparison with other preventive measures. However, this solution could be considered in the context of Quebec occupational health and safety legislation that advocates the elimination of the danger at the source. The societal benefit of the reassignment of pregnant teachers during outbreaks or epidemics appears to be extremely limited, although some risk reduction could be provided to the specific group concerned. If chemoprophylaxis is indicated to control an outbreak in an institution, it should be offered to educators.

ACKNOWLEDGEMENTS: This study was done in connection with an expert assessment requested by the "Table de concertation nationale en santé au travail" in the province of Quebec. Besides the authors, the group of experts included Myreille Arteau of the "Régie régionale de la Santé et des Services sociaux de Lanaudière", and Claude Tremblay of the "Département de microbiologie de l'Hôpital Hôtel-Dieu de Québec”. The following individuals also provided useful information: Nancy Rosenstein, Centers for Disease Control and Prevention, Atlanta; James M Stuart, Public Health Laboratory Service, London; Anne Perrocheau, Institut national de veille sanitaire, Paris; Shelley Deeks, Health Canada, Ottawa; Monique Douville-Fradet, Ministère de la santé et des services sociaux, Québec; Elisabeth Lajoie, Direction de la santé publique de la Montérégie, Longueuil (Québec). In addition, Robert Plante and Denis Laliberté, Direction de la santé publique de la région de Québec, provided useful comments on the manuscript.

\section{REFERENCES}

1. De Wals P, Dionne M, Douville-Fradet M, Boulianne N, Drapeau J, De Serres G. Impact of a mass immunization campaign against serogroup C meningococcus in the province of Quebec, Canada. Bull World Health Organ 1996;74:407-11.

2. Bureau de surveillance épidémiologique, Ministère de la Santé et des Services sociaux du Québec. Épidémiologie des infections invasives à méningocoque, année 2001. Flash Méningo 2001;1:1-6.

3. Loi sur la santé et la sécurité du travail. Québec: Éditeur officiel du Québec, 1983.

4. Brandtzaeg P. Pathogenesis of meningococcal infections. In: Cartwright K, ed. Meningococcal Disease. Chichester, United Kingdom: John Wiley \& Sons, 1995:71-114.

5. Cartwright K. Meningococcal carriage and disease. In: Cartwright K, ed. Meningococcal Disease. Chichester, United Kingdom: John Wiley \& Sons, 1995:71-114.

6. Neal KR, Nguyen-Van-Tam JS, Jeffrey N, et al. Changing carriage rate of Neisseria meningitidis among university students during the first week of term: Cross sectional study. BMJ 2000;320:846-9.

7. Le Saux N, Ashton F, Rahman M, et al. Carriage of Neisseria species in communities with different rates of meningococcal disease. Can J Infect Dis 1992;3:60-4.

8. Conyn-van Spaendonck MAE, Reintjes R, Spanjaard L, van Kregten E, Kraaijeveld AG, Jacobs PHA. Meningococcal carriage in relation to an outbreak of invasive disease due to Neisseria meningitidis serogroup C in the Netherlands. J Infect 1999;39:42-8.
9. Maiden MC, Stuart JM, The UK Meningococcal Carriage Group. Carriage of serogroup C meningococci 1 year after meningococcal $\mathrm{C}$ conjugate polysaccharide vaccination. Lancet 2002;359:1829-31.

10. Wall R, Wilson J, MacArdle B, Vellani Z. Meningococcal infection: Evidence for school transmission. J Infect 1991;23:155-9.

11. Riordan T. A college outbreak of group $\mathrm{C}$ meningococcal infection: How widely should investigation and prophylaxis extend? Commun Dis Rep CDR Rev 1997;7:R5-9.

12. Davies AL, O'Flanagan D, Salmon RL, Coleman TJ. Risk factors for Neisseria meningitidis carriage in a school during a community outbreak of meningococcal infection. Epidemiol Infect 1996;117:259-66.

13. Fitzpatrick PE, Salmon RL, Hunter PR, Roberts RJ, Palmer SR. Risk factors for carriage of Neisseria meningitidis during an outbreak in Wales. Emerg Infect Dis 2000;6:65-9.

14. Kristiansen BE, Tveten Y, Jenkins A. Which contacts of patients with meningococcal disease carry the pathogenic strain of Neisseria meningitidis? A population based study. BMJ 1998;317:621-5.

15. Jones D. Epidemiology of meningococcal disease in Europe and the USA. In: Cartwright K, ed. Meningococcal Disease. Chichester, United Kingdom: John Wiley \& Sons, 1995:147-57.

16. National Advisory Committee on Immunization (NACI). An Advisory Committee Statement (ACS). Statement on recommended use of meningococcal vaccines. Can Commun Dis Rep 2001;27:2-36. 
17. Tsang RSW, Squires SG, Tam TWS. Characterization of Neisseria meningitidis strains isolated from invasive meningococcal disease in Canada in 2001. Can J Microbiol 2003;49:633-8.

18. Taha MK, Achtman M, Alonso JM, et al. Serogroup W135 meningococcal disease in Hajj pilgrims. Lancet 2000;356:2159.

19. Bruce MG, Rosenstein NE, Capparella JM, Shutt KA, Perkins BA, Collins M. Risk factors for meningococcal disease in college students. JAMA 2001;286:688-93.

20. Erickson L, De Wals P. Complications and sequelae of meningococcal disease in Quebec, Canada, 1990-1994. Clin Infect Dis 1998;26:1159-64.

21. Woodhouse S, Hunter PR. Risk of invasive meningococcal disease among school workers in Cheshire, United Kingdom. Clin Infect Dis 2001;32:1795-7.

22. Rothman KJ. A sobering start for the cluster busters' conference. Am J Epidemiol 1990;132(Suppl 1):S6-13.

23. Gilmore A, Stuart J, Andrews N. Risk of secondary meningococcal disease in health-care workers. Lancet 2000;356:1654-5.

24. Boutet R, Stuart JM, Kaczmarski EB, Gray SJ, Jones DM, Andrews N. Risk of laboratory-acquired meningococcal disease. J Hosp Infect 2001:49:282-4.

25. Jacobson JA, Filice GA, Holloway JT. Meningococcal disease in day-care centers. Pediatrics 1977;59:299-300.

26. Sáez-Nieto JA, Perucha M, Casamayor H, et al. Outbreak of infection caused by Neisseria meningitidis group $\mathrm{C}$ type 2 in a nursery. J Infect 1984;8:49-55.

27. Leggiadro RJ, Baddour LM, Frasch CE, LaFrain JF, Gaia SM, Thomas JA. Invasive meningococcal disease: Secondary spread in a day-care center. South Med J 1989;82:511-3.

28. O'Donovan D, Iversen A, Trounce J, Curtis S. Outbreak of group C meningococcal infection affecting two preschool nurseries. Commun Dis Public Health 2000;3:177-80.

29. Feigin RD, Baker CJ, Herwaldt LA, Lampe RM, Mason EO, Whitney SE. Epidemic meningococcal disease in an elementary school classroom. N Engl J Med 1982;307:1255-7.

30. Hudson PJ, Vogt RL, Heun EM, et al. Evidence for school transmission of Neisseria meningitidis during a Vermont outbreak. Pediatr Infect Dis J 1986;5:213-7.

31. Sutton T, Ip S. A cluster of meningococcal meningitis cases in an Auckland secondary school. N Z Med J 1987;100:153.

32. Robinson P, Taylor K, Tallis G, et al. An outbreak of serogroup C meningococcal disease associated with a secondary school. Commun Dis Intell 2001;25:121-5.

33. Ferson M, Young L, Hansen G, et al. Unusual cluster of mild invasive serogroup $\mathrm{C}$ meningococcal infection in a university college. Commun Dis Intell 1999;23:261-4.

34. Jacobson JA, Camargos PAM, Ferreira JT, McCormick JB. The risk of meningitis among classroom contacts during an epidemic of meningococcal disease. Am J Epidemiol 1976;104:552-5.

35. Sheehe PR, Feldman HA. Re: "The risk of meningitis among classroom contacts during an epidemic of meningococcal disease." Am J Epidemiol 1977;106:340-2.
36. Hastings L, Stuart J, Andrews N, Begg N. A retrospective survey of clusters of meningococcal disease in England and Wales, 1993 to 1995: Estimated risks of further cases in household and educational settings. Commun Dis Rep CDR Rev 1997;7:R195-200.

37. De Wals P, Hertoghe L, Borlée-Grimée I, et al. Meningococcal disease in Belgium. Secondary attack rate among household, daycare nursery and pre-elementary school contacts. J Infect 1981;3(Suppl 1):53-61.

38. Zangwill KM, Schuchat A, Riedo FX, et al. School-based clusters of meningococcal disease in the United States. Descriptive epidemiology and a case-control analysis. JAMA 1997;277:389-95.

39. Schwartz B, Moore PS, Broome CV. Global epidemiology of meningococcal disease. Clin Microbiol Rev 1989;2(Suppl):S118-24

40. Rosenstein NE, Perkins BA, Stephens DS, Popovic T, Hughes JM. Meningococcal disease. N Engl J Med 2001;344:1378-88.

41. De Wals P, De Serres G, Niyonsenga T. Effectiveness of a mass immunization campaign against serogroup $\mathrm{C}$ meningococcal disease in Quebec. JAMA 2001;285:177-81.

42. Miller E, Salisbury D, Ramsay M. Planning, registration, and implementation of an immunisation campaign against meningococcal serogroup $\mathrm{C}$ disease in the UK: A success story. Vaccine 2001;20(Suppl 1):S58-67.

43. Bose A, Coen P, Tully J, Vinner R, Booy R. Effectiveness of meningococcal conjugate vaccine in teenagers in England. Lancet 2003;361:675-6.

44. Feavers IM. Meningococcal vaccines and vaccine developments. In: Pollard AJ, Maiden MCJ, eds. Meningococcal Vaccines. Methods and Protocols. New Jersey: Humana Press, 2001:1-22.

45. ACIP. Prevention and control of meningococcal disease. Recommendations of the Advisory Committee on Immunization Practices. MMWR Recomm Rep 2000;49(RR-7):1-10.

46. Laboratory Centre for Disease Control. Canadian Consensus Conference on Meningococcal Disease. Guidelines for control of meningococcal disease. CMAJ 1994;150:1825-39.

47. Analysis of endemic meningococcal disease by serogroup and evaluation of chemoprophylaxis. J Infect Dis 1976;134:201-4.

48. Samuelsson S, Hansen ET, Osler M, Jeune B. Prevention of secondary cases of meningococcal disease in Denmark. Epidemiol Infect 2000;124:433-40.

49. Scholten RJ, Bijlmer HA, Dankert J, Valkenburg HA. Secondary cases of meningococcal disease in The Netherlands, 1989-1990: A reappraisal of chemoprophylaxis. Ned Tijdschr Geneeskd 1993;137:1505-8.

50. Jackson LA, Alexander ER, DeBolt CA, et al. Evaluation of the use of mass chemoprophylaxis during a school outbreak of enzyme type 5 serogroup B meningococcal disease. Pediatr Infect Dis J 1996;15:992-8.

51. Gonzalez de Aledo Linos A, Garcia Merino J. Control of a school outbreak of serogroup B meningococcal disease by chemoprophylaxis with azithromycin and ciprofloxacin. An Esp Pediatr 2000;53:412-7.

52. Round A, Evans MR, Salmon RL, et al. Public health management of an outbreak of group C meningococcal disease in university campus residents. Eur J Public Health 2001;11:431-6. 


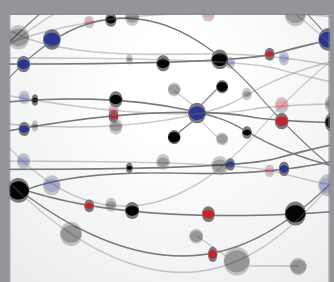

The Scientific World Journal
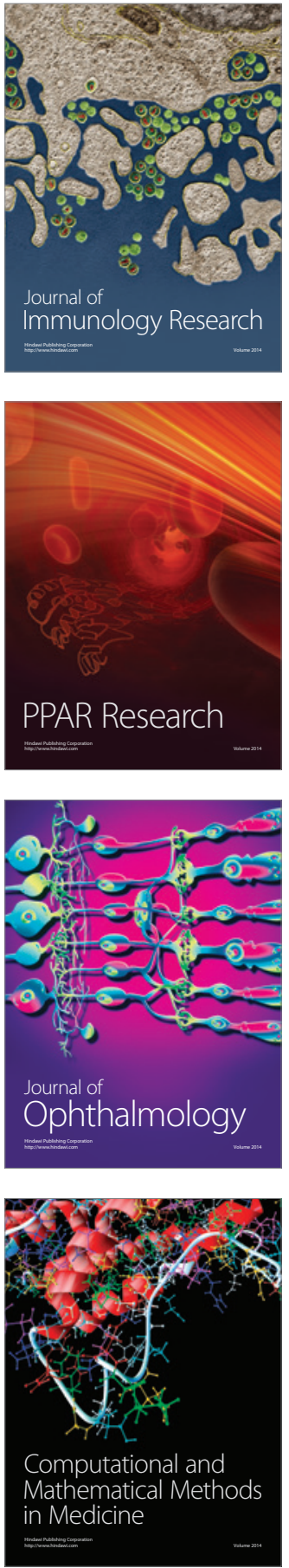

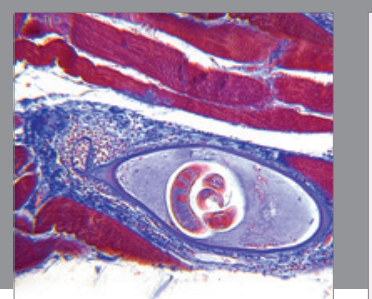

Gastroenterology Research and Practice

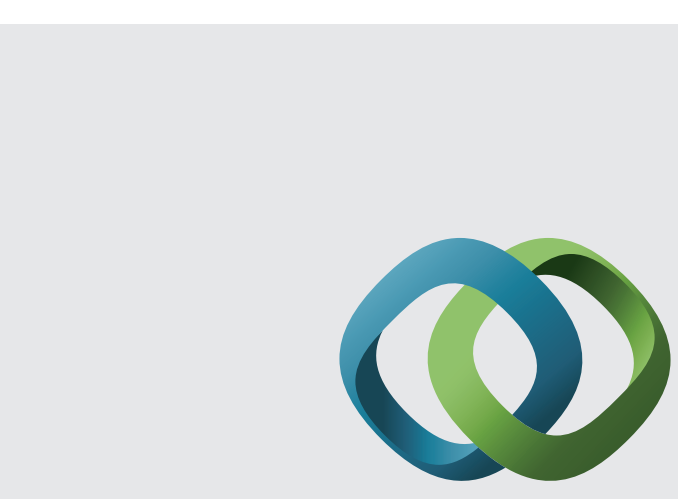

\section{Hindawi}

Submit your manuscripts at

http://www.hindawi.com
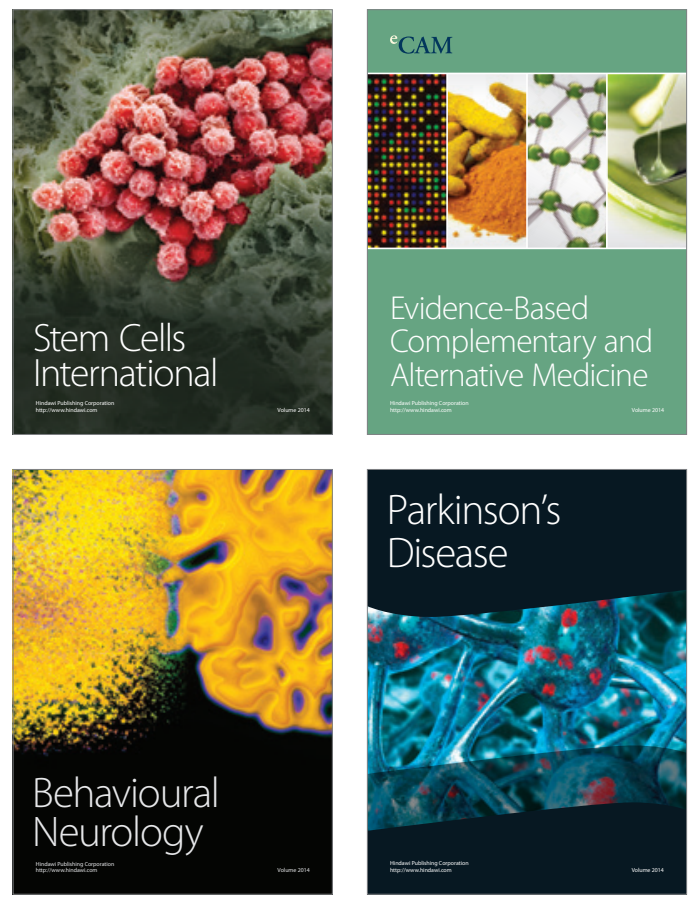
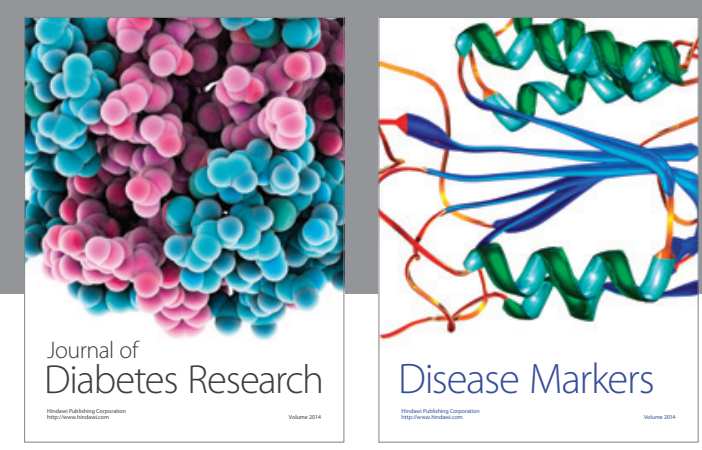

Disease Markers
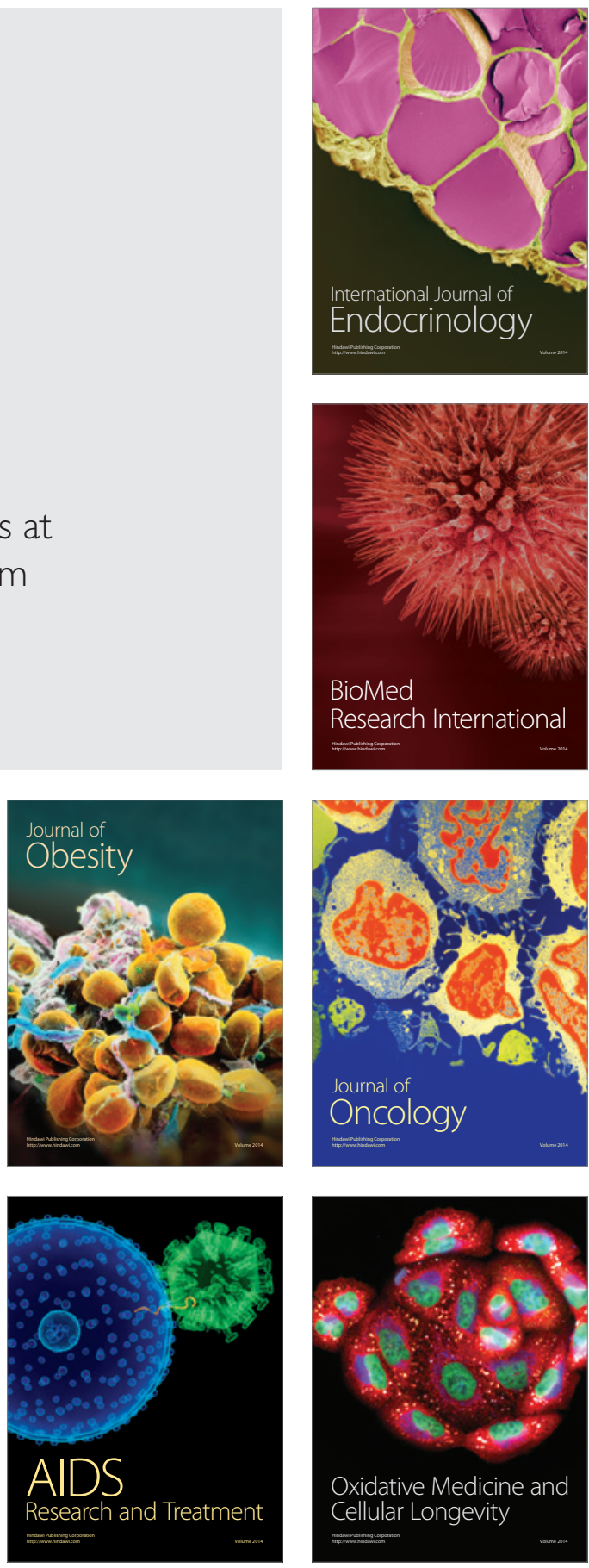